\title{
RESOURCES AND ENVIRONMENT FOR ECONOMIC DEVELOPMENT
}

\author{
Yadab Raj Sharma \\ Department of Economics Education, T.U., TRM Campus, Birgunj \\ yadabrajsharma@yahoo.com
}

\begin{abstract}
The study of environmental economics is essential and is concerned to allocation of resources among alternative uses in such a way that there is an efficient reduction of the waste, discharged to the environment which causes an increase in welfare. Excessive exploitation of the natural resources brings negative changes in the environment mainly in ecological balance. Resources are essential for economic development but modernization, industrialization and some kinds of socio - cultural practices are degrading the natural environment. This article presents the way of the sustainable development and control of the environmental problem due to developmental activities. Some recommendations are made which may help to improve the environment, and slowdown the rising damage.
\end{abstract}

\section{Keywords}

Natural resources, technology, environment, exploitation, degradation, pollution, development.

\section{Introduction}

All materials converted into final consumer or producer goods are ultimately discharged to the environment. Time may be gained to develop the technology that may control discharge of waste according to required standards. Some newer technology is required to be developed to maintain an overall materials balance. We know that economic development and preservation of a sound environment are not necessarily in conflict. So there is no choice between economic development and quality of the environment. But economic development cannot be good for welfare if there is a faulty distribution as obtained in every country. Technology has helped man to gain some control over the environment but man should not think that he is master of the environment, because his efforts to gain control over the environment are in conflict with nature, which punishes 
him in many ways. On the one side technology is a blessing but on the other side it is a curse also. Science and technology have adopted so many measures to produce material goods, but they have not been able to measure human values and reaction. Science and technology have brought many blessings to man. These are their good aspect. But man has to measure the values of noise, destruction of landscape and effect of pollutants. These are their bad aspects.

Society is responsible for handling its technology. It should be in a such a way that there will be no problem by the rising population. I mean to say that peace should be maintained and there should be enough food, fuel, safe drinking water, shelter, medicare and basic education in society. We see that achievement in these areas has not been satisfactory. Employment is not available for every able-bodied person. Similarly basic necessities of life are not enough. Population is increasing and at the same time resources are decreasing. It is absolutely essential that we keep a check on ourselves. We should move forward without inflicting too much damage on environment and realize our responsibilities to accept the limitation of technological progress. Advanced countries will have also to curtail their pursuit of economic growth under a variety of limitation, particularly those of depleting resources and deteriorating environment.

Resources are essential for economic development. They are natural and manmade from natural materials. Modern technology depends on large amount of different resources in the production process. Various essential and advanced products have been built with new steels, alloys and advance materials. Steel is alloyed with minerals, such as nickel, manganese, molybdenum, and others to produce alloy steel. Aluminum is made from bauxite. The modern petrochemical industry is based on petroleum. It is used both for industry and transportation. Other materials such as plastics are replacing natural materials like iron cotton and wood. But colorless and highly inflammable gasses like ethylene and acetylene are derived from crude oil, which are raw materials to produce plastics and synthetic fibers. We use resources from the environment on a very large scale. These resources are air, water, soil, minerals and are converted into commodities, energy and residuals. The advance of technology depends on new materials to meet the requirements of new processes. Reserve of resources like oil, coal and so on can not last indefinitely. So depletion of the resources will be the great problem for us. The environmental problems and mineral exploitation may create relative to human values, and institutions required controlling deterioration and effect improvement.

\section{Environment and Development}

Environment means external conditions or influences under which an organism lives. Environment and man are related through man's activities. Our activities produce waste, which is mixed to the environment. Degradation of the environment causes several complications which influence all life. The use of renewable and nonrenewable natural resources has impact on human welfare. The adverse impact cause ill health for man, degradation of the soil, forest depletion and other pollutions. The degree of the environmental problem has increased due to the fast rate of growth of population and rising per capita demand. No one has a right to pollute the common property like air, water or land although this is being done everywhere, thus creating so many problems. We should try to resolve some environmental problems by suggesting taxation, subsidy, or other measures to control environmental degradation. Population and natural resources both are closely interrelated to each other. Human resources is quite essential for the socio - economic development of a nation or any region but over population growth is threatening the very existence of human life by creating an imbalance between population 
and resources. Population growth in itself is not a problem but we have to consider the potentiality of resources. The mode of utilization of resources should maintain sustainability in the society.

\section{Use of the Resources}

It is a fact that the poor and backward countries will have to rely basically on scientific development and exploitation of their renewable resources, such as agriculture, forest and water, so that they are able to provide necessities in such a way that there is an equitable distribution, and they do not overtax the carrying capacity of the earth. Development of their economies based on renewable resources will minimize the environmental degradation, but probably no backward country would agree to base its economy mainly on renewable resources, simply because no industrial advance country would be prepared to restart its economy largely based on renewable resources. Industrially advanced countries are using minerals as inputs, which create environmental problems. Great damage has already been done by the industrially advance countries. So the backward country should study the environmental issues for economic planning for the following reasons:

1. The interests of backward countries would be influenced by action of industrially advanced countries to tackle their own environmental problems.

2. Backward countries have their own environmental problems arising basically from poverty and underdevelopment.

3. The preservation and care of common resources of the atmosphere and water are of concern to mankind.

These considerations will affect the course of development in backward countries, which in turn will influence the way of living of the people.

\section{Pollution of the Environment}

Pollution of the environment is from natural and man-made causes. Of course, environmental pollution is the unfavorable alternation of our surrounding largely as a by - product of man's activities. Every year millions of tons of gaseous and particulate pollutants are injected into the atmosphere both through natural processes and human activity. The capacity of the environment to absorb pollution is limited. Any source which adds to pollution is a threat to life. The population is increasing and more people are using the resources each year, and the average consumption per person is increasing each year, and, so, the waste generation is increasing with its consequences. Many kinds of pollutants float about the earth in the atmosphere and water, producing harmful effects at great distances from the point of discharge or generation.

Common air pollutants such as Aldines, Ammonia, Arsenic, Carbon monoxide, Chlorines, Hydrogen Cyanides, Hydrogen fluorides, Hydrogen supplied, Nitrogen oxide, Carbonyl Chloride, Sulphus dioxide, Suspended particles (Ash, Smoke etc) causes several pathological effect on man from different sources. Establishment of industries far from the settlement area, industries with tall chimneys, use of alternative sources of energy in place of combustible sources, reforestation, avoiding of nuclear explosions, check of the population growth rate, providing environmental education are the major methods to reduce air pollution.

Water pollution is becoming serious owing to indiscriminate discharge of untreated industrial and municipal effluents into the water resources of several nations. Plants and animals require water that is moderately pure and they cannot survive if their water is loaded with toxic chemicals or harmful microorganism. Petroleum products, pesticides and herbicides, heavy metals, hazardous wastes, exess organic matter, 
sediments, infectious organisms are the major water pollutants. Domestic wastes may cause different diseases such as typhoid, cholera, dysentery, jaundice etc. Inorganic compounds of nitrate and phosphates increase the rate of eutrophication. Muddy water causes reduction in dissolved oxygen which leads to the reduction of aquatic organisms. Cadmium obtaining by industries caused kidney damage, hypertension, anemia etc. So water pollution should be controlled through minimizing the sources of water pollutants by human efforts.

Degradation of soil condition which is unfavorable for plants and animals is called soil pollution. Soil pollution is a build up of toxic chemical compounds, salts and other materials that can affect plant and animal life. The earth has great absorptive capacity, but it is not limitless. Once the limit is crossed, the quality of the soil begins to deteriorate. Pesticides, herbicides, industrial wastes, chemical fertilizer, dust particles from mine and industries, fluorides and acid - rains etc are major soil pollutants. Sources of soil pollutants should also be controlled.

Modern society is a waste-generating society. The industrial societies of developed countries are building up gigantic waste heaps of civilization. As a result of this air, water and land are becoming highly polluted. Conditions are equally serious in the industrialized zones of developing countries. In the absence of adequate safeguards, economic development will be checked.

\section{Conclusion}

Industrial and other activities have become very complex and seem to pose a threat to the environment of the countries. The consequences of individual behaviour have increasing impact on the society and the environment. Though each individual is free to do what they like but it has become essential to put constraints on their activities, otherwise both society and the environment will be in danger of collapse. We must think over the sustainable development and control the environmental problem. Rising population comes up against the limit amount of different natural resources. Rising resources consumption and production must cause a rapid depletion of resources. This will leave little for the futrue. So compulsory population control is essential. Gradual switch - over to renewable resources from nonrenewable resources must be completed by near future to minimize the mechanization and increase in employment of human labour. Scientific management of agriculture, forest and water resources is a must. We should think over the efficient use of the available resources. The misuse of resources leads to over production of wastes eventually poses a threat to survival of mankind.

\section{References}

Acharya, K..P. and Bhatta, B.D., (1999). Population studies, Kathmandu: Vidyarthi Pustak Bhandar.

Bhatt, B.D. (2001). Environmental education, Kathmandu: Vidhyarthi Pustak Bhandar.

Colinvax, P. A. (1973). Introduction to ecology, New York: John Wiley and Sons.

Sexena, H.M. (1999), Environmental geography, New Delhi: Rajwat Publication.

Sharma, R.C. (1999), Population trends resources and environment, Dhanpat Raj Publishing Company.

Singh, Y.K., (2006). Environmental Science. New Delhi: New Age International Publishers.

Yadav, U.R. (2005). Ecology and Psychology, Kathmandu: Raj Offset Press. 